\title{
Modern Information Technology Provides an Innovative Model for College English Teaching
}

\author{
Dan Li \\ English Department \\ Liaoning Institute of Science and Technology \\ Benxi, China
}

\begin{abstract}
The integration of information technology and college English teaching is to combine the needs of classroom teaching activities with effective application of modern information technology, incorporate it into the teaching and learning of the curriculum so as to improve the efficiency of teaching and learning. The purpose of this paper is indicate that combination of modern information technology with college English teaching will enrich college English teaching content, change the traditional teaching mode, cultivate students' learning ability, improve students' comprehensive quality and skills, and thus enhance students' learning effect. However, in the application of multimedia in English teaching, there are many problems. And effective strategies to deal with such problems are also illustrated with stress on teaching mode of teachers. The main analysis of the method is to improve the teachers' teaching design with modern information technology. Compared with the traditional teaching methods, it can bring a new life to the college English class. The abundant teaching content strengthened by modern teaching means, thus brings the English classroom brand-new realm.
\end{abstract}

Keywords—integration, design, multimedia technology, innovation, skills

\section{INTRODUCTION}

The development of social economy promotes the development of education. With the development of economic globalization, the connection and cooperation between different regions and countries are increasingly strengthened. The arrival of "Internet plus" era is not only the inevitable result of the development of network society, but also a strong driving force for the progress of knowledge society. The Internet has been actively integrated with factors from all walks of life in society, and its integration with education has led to a higher and higher level of educational informatization. The teaching of English courses plays an important role in the cultivation of English majors.

Foreign language audiovisual education under the new media era under the information technology, digital technology and multimedia technology, gradually break media restrictions and form the new concept of English language teaching with media literacy fusion. This teaching model significantly improves students' intercultural communication ability, enables students to further integrate information, realizes the reform and innovation of foreign language teaching, actively improves students' language and communication ability, and promotes the reform of college English teaching. The integration of information technology and curriculum refers to a new teaching method that combines information technology and information resources with English teaching under the guidance of modern education theory for teachers to accomplish the teaching tasks of the curriculum together. This integration is the integration of information technology with cultural characteristics and English subject, which integrates knowledge and accomplishment. This teaching mode is a kind of which can not only play teachers' leading role, but can also fully embody the students' main body status of the teaching way. It fundamentally change the traditional teaching concept and the corresponding learning goals, methods and means of evaluation so that the students can study in different stage through the selection of effective technology, information acquisition, analysis and synthesis to cultivate their innovation ability. [1]

\section{INTEGRATING INFORMATION TECHNOLOGY AND ENGLISH TEACHING TO IMPROVE THE EFFICIENCY AND EFFECT OF TEACHING AND LEARNING}

\section{A. Using multimedia computer technology to enrich college English teaching content and cultivate students' learning ability}

The integration of information technology and English course teaching is usually driven by various thematic tasks. As a practical language discipline, teachers should not only set the prescribed teaching objectives, but also expand the teaching content for students to understand the local customs and social features of English-speaking countries, increase their humanistic knowledge and improve their comprehensive quality. Therefore, with the help of computer multimedia technology and network teaching resources, the teaching content can be changed from being abstract and static to concrete and colorful through multiple ways of sound and sounds, so as to increase students' senses and audio-visual enjoyment. Teachers can select the learning theme when preparing lessons, let students use various information media resources to independently study and find materials, and then adopt the teaching method of classroom shared to enrich the teaching content and learn together. Multimedia teaching combines pictures and texts to enable students to put forward problems in a timely manner, which greatly improves students' interest in learning and enables them to take the initiative in learning and self-study. Students can also choose their own articles according to the actual situation and their own needs, and learn the content they are interested in repeatedly. It allows 
students to be masters of learning what they want on their own, tapping into their own potential creativity. Pluralistic thinking also fills the students with enthusiasm, interest. With the help of information technology, through active participating in classroom activities, games and a variety of ways to strengthen the knowledge of the English words, sentences and even memorization, understanding and using of the concept of language, in imperceptible in, they improve the independent inquiry learning ability. [2]

\section{B. Using multimedia technology to enrich teaching methods and change the traditional teaching mode}

With the rapid development of information technology, English teaching aided by computer has developed rapidly. The integration of information technology and English teaching is one of the important steps of English teaching reform. Therefore, as an English teacher, we must have a full understanding of the integration of information technology and English teaching classroom, and understand its significance and use. English teaching aided by computer means that teachers take computer as the core aided with projector, DVD player, tape recorder and multi-function language experiment, information technology to provide learners with a completely real language environment. The application of multimedia information technology in college English teaching is unique, advanced and efficient, which changes the traditional teaching mode and achieves the optimization of teaching. By using multimedia to simulate a variety of situations, teachers incorporate students into the English classroom environment, give play to their subjective initiative, increase the interest of the students. Due to the convenient, flexible and efficient information technology, multimedia education system can establish all-round multi-level dynamic language environment through the computer and network, stimulate students' sensory organs, make the content of the abstract image vivid and interesting and thus greatly stimulate students' curiosity and desire for knowledge.

\section{Using multimedia technology to enhance students' interest in learning}

"Interest is the best teacher." Real interest can help students and arouse their enthusiasm for learning content and enthusiasm for learning, so interest is one of the important factors that affect students' learning effect. The combination of English teaching and modern information technology can improve students' interest in learning to some extent. For example, multimedia English teaching, a relatively new point is the dynamic teaching mode which gets rid of the static learning process before boring. Teaching in the mode of dynamic transmission, with the interesting blend of sound and picture, can turn the inherent dull and abstract knowledge into image, vivid and specific. Such a teaching form can create an interesting and vivid teaching environment, form a happy and free classroom learning atmosphere, and enhance the lively and interesting teaching. The combination of novel teaching mode and information technology in English teaching can attract students' attention for a long time, stimulate students' interest in learning, and enable students to participate in learning with a positive and enthusiastic attitude, so as to achieve the best learning effect.

\section{Using multimedia technology to improve students comprehensive quality and skills}

The integration of information technology and English teaching makes the teaching content more abundant and intuitive, teaching methods more diverse and teaching results more efficient. Practice, cooperation, participation and communication should be advocated and task-based teaching methods should be combined to improve students' language use, which is conducive to enhancing students' comprehensive quality and ability. To the same problem ,students think, analysis, discuss and communicate, from different angles, with an open mind, which is conducive to divergent students thinking and train students thinking mode. At the same time, students can learn together, explore knowledge, and deal with things so they learn to develop, communicate with each other , share the learning results, and experience the fun of the learning process. It can enhance their own comprehensive quality and skills by their communication and cooperation .The meaning is far more profound and positive than the English language itself. [3]

\section{E. Using multimedia technology to create teaching situation with information technology to promote students' memory ability}

In the traditional English teaching, we focus on the explanation of grammar knowledge. However, the grammar knowledge is probably out of touch with the real situation and it cannot arouse students' interest in learning. There is no such problem in the teaching mode with modern information technology. It can create a simulation of the situation, a description of natural sound, shape, color vivid color with the sound, image, animation and all the things together. The information capacity of multimedia is very large, from which we can find a lot of materials that can help to set up the situation. When we acquire resources, we do not need to be constrained by space and time, and we share them to a large extent. Its interactivity enables students to study more actively and expand their thinking space. Its hypertext link and the human way of thinking fit so that students' thirst for knowledge is satisfied, providing students know more knowledge. In general, modern media can break the barriers of time and space, gather all kinds of different information together, and create a real situation conducive to English learning. Applying information technology to English teaching can effectively promote the teaching effect. Multimedia information technology can stimulate students' senses and improve their memory of learning. Human being learn through the organic combination of their mouth, eyes, nose, mouth and tongue, and transmit the information and signals received by the outside world to the brain. After analyzing the information, the brain turns the information from the outside world into its own knowledge. Multimedia information technology breaks through the monotony and dullness of traditional teaching mode by means of this learning method involving senses, and makes use of the integration of information technology and English teaching to provide students with intuitive and effective information materials, which is beneficial to enrich students' thinking and profound understanding of English. 


\section{F. Using multimedia technology to guide students to study independently}

Through the establishment of the website, the researchers reduce or even eliminate agricultural market information asymmetry phenomenon of production for farmers. Provided comprehensive information to offer aid in the production, farmers can accurately grasp the market demand and make intelligent agricultural production behaviors. For English learners in China, lack of real language environment, the lack of language practice opportunities is the biggest obstacle. And in the actual teaching of school education, attention is often only paid to the words, sentence patterns of mechanical teaching, ignoring its concrete application, especially for beginners of English schoolchildren. More teachers now apply information technology combined with the teaching material content, create good English learning situation, and make the students form of learning content more rich, more innovative, more real, and more vivid. Language learning cannot be separated from the environment. If you can't create a good English learning atmosphere in class and arouse the enthusiasm of students learning English actively, it can make the students feel bored about classroom activities and lose participation enthusiasm. The active participation of students is the key point. [4]

\section{THE FOLLOWING STRATEGIES ARE SUGGESTED TO IN THE APPLICATION OF COMBINING INFORMATION TECHNOLOGY AND ENGLISH TEACHING MODE}

\section{A. Interaction between teachers and students should intensified}

In the use of information technology, we often encounter similar situations in the process of teaching. For example, teachers pay too much attention to colorful courseware, focus on new and diverse forms of teaching, but ignore the in-depth understanding of teaching content, especially desalinating some teaching heavy, difficult points. The teacher becomes a multimedia operator. The teacher can be seen only clicking the mouse, demoing courseware from beginning to end, step by step. In the course of teaching, the teachers be totally dependent on courseware and lack of the interaction with the students, which seriously affects the effect of multimedia teaching. The computer will replace the teacher's teaching and the teacher's emotional education in the classroom is gone without the interaction with the students. Language learning becomes a one-way passive absorption.

\section{B. The teaching design ability of teachers needs to be improved}

Teaching design is a systematic method to solve problems in teaching, so that teachers can reasonably and effectively arrange various factors in the teaching process and ensure the smooth realization of teaching objectives. Due to the influence of traditional teaching ideas, many teachers believe that the key to teaching is teachers' teaching and students' learning, and teaching design is nothing more than teachers preparing lessons before class. Therefore, in the use of multimedia for English teaching, the overall layout and design of teaching is not enough, so the teaching thinking is confused. The teaching process is either completely depending on the teaching courseware or experience and situation , with blindness and randomness. Such kind of teaching will lack of initiative and creativity.

\section{The information provided should be moderate}

According to the teaching objectives of information technology, teachers should create problems conducive to exploration for students, guide independent learning and cooperative learning. The creation of the situation should be combined with the psychological characteristics of students, innovative and interesting, entertaining, which is conducive to the successful completion of teaching objectives. When using multimedia teaching, teachers add various forms of materials to attract students' attention. Due to the rich content of courseware and large amount of information, some teachers, consciously and unconsciously speed up the pace of class, affecting the students' absorption of the key points and difficult points of the course. Then it will affect the realization of our teaching objectives and students' imagination. Multimedia teaching is only a means of auxiliary teaching which cannot replace the teachers whose basic responsibility is "preaching, teaching and solving the mystery". [5]

\section{Software development needs to be improved, and corresponding teaching facilities need to be popularized to a large extent}

The important position of multimedia courseware in classroom teaching is beyond doubt. However, many foreign language teachers, especially the experienced teaching teachers, are too old to own innovative teaching ideas and can't apply distinctive teaching methods through multimedia technologies as a result of the limitation of the computer application level. And it's hard to find partners at the same time know both English and proficient in the software development of multimedia technology. Some young teachers pay too much attention to the forms of courseware, so key and difficult is not outstanding. Because multimedia technology needs a lot of hardware facilities. Therefore, the school needs to invest a lot of capital and equipment to improve its application in teaching. In addition, teachers who are not familiar with multimedia teaching should be trained.

\section{E. The teacher's teaching technique of appliction need to be improve.}

If we want to apply modern educational technology, we must base on modern educational theory. Modern education is based on students as the main body of education. Therefore, when teachers use information technology in teaching, they aim to arouse students' interest .Only by changing the key content of teaching from imparting knowledge blindly to improving comprehensive quality can we make a great breakthrough in English teaching.

English learning is practical, so in the teaching process, the teacher must have a lot of dialogues and communications with students in order to develop students' oral English ability better so that students can be acquire the language better. However, some teachers misunderstand the essence of integrated of information technology and English and excessively pursue the exquisite degree and display pattern of multimedia lecture courseware. 


\section{REFERENCES}

\section{CONCLUSION}

The integration of Information technology and English subject enrich the teaching content, optimize the teaching process, and enhance the students' interest in learning. Stimulate the integration of English teaching and learning technology for modern English teaching has provided a broad heaven and earth, led to the deepening of teaching reform, made education more profound changes which have taken place in teaching field. Teachers should re-recognize the dominant position in information-based teaching practice, promote the change of roles of teachers and students according to the needs of flipped classroom, and give full play to the auxiliary role of teaching to escort students' independent learning. The use of modern information technology requires our teachers to keep up with the development of the times, keep learning and improve our teaching practice. At the same time, we also need to have the concept of lifelong learning
[1] Wang Jie. Application of interactive teaching method in political theory course teaching in universities [J]. Chinese adult education, 2009.

[2] Luo Chengfang. Research on strategies of implementing autonomous learning in English teaching in TV university [D]. Chongqing: southwest university, 2008.

[3] Wang Lili, Yang Fan, research on the reform and development of college English teaching under the background of "Internet plus" [J]. Hei Longjiang higher education research,2015

[4] Liu Jin. Discussion on English teaching reform in higher vocational colleges in the era of "Internet plus" [J]. Science and technology innovation herald, 2016.

[5] Feng Zhenyu, problems and countermeasures in multimedia assisted English teaching [J], educational technology 2005.9 